\title{
The Puzzling Persistence of Process-Based Constitutional Theories
}

\author{
Laurence H. Tribe†
}

In deciding constitutional cases, the Supreme Court has often invoked a vision of how politics should work, justifying judicial intervention as a response to supposed gaps between that vision and political reality. Legislation or other governmental action is of constitutional concern, the Court suggests, when it seems to obstruct political representation and accountability-by blocking speech or voting, for example-or when it reveals the existence of past or present obstructionsby distributing the law's benefits and burdens in ways that show a particular group to have been denied fair representation. ${ }^{1}$ By invalidating legislative or administrative acts of this sort, the Court can reason, it avoids controversial judgments about substantive issues left open by the Constitution's text and history, and safeguards the representative character of the political process.

It is easy to see why courts would be attracted to this way of describing the content and role of constitutional law. Such an account permits courts to perceive and portray themselves as servants of democracy even as they strike down the actions of supposedly democratic governments. ${ }^{2}$

$\uparrow$ Professor of Law, Harvard University. A.B., Harvard, 1962; J.D. 1966. I would like to acknowledge the extensive help of Professor Patrick O. Gudridge of the University of Miami Law School. Professor Gudridge and I are collaborating on what we hope will be a series of essays on the foundations of constitutional law. This Article is the introduction to that joint enterprise.

1. The best known statement of this view by the Supreme Court was written by Justice Stone in United States v. Carolene Prods. Co., 304 U.S. 144, 152 n.4 (1938):

It is unnecessary to consider now whether legislation which restricts those political processes which can ordinarily be expected to bring about repeal of undesirable legislation, is to be subjected to more exacting judicial scrutiny under the general prohibitions of the Fourteenth Amendment than are most other types of legislation ....

Nor need we enquire whether similar considerations enter into the review of statutes directed at particular religious, ... or national, ... or racial minorities, . . ; whether prejudice against discrete and insular minorities may be a special condition, which tends seriously to curtail the operation of those political processes ordinarily to be relied upon to protect minorities, and which may call for a correspondingly more searching judicial inquiry.

2. The doctrinal forms in which the Supreme Court expresses its decisions at least sometimes support the view that the Court is attempting to portray itself as working 
But other constitutional theorists, unencumbered by the judiciary's rhetorical needs, also find the idea of perfecting process, and process alone, to be powerfully magnetic. ${ }^{3}$ In the most recent and lucid argument for a process-perfecting view of constitutional law, John Ely's Democracy and Distrust, the vision is boldly stated:

[C]ontrary to the standard characterization of the Constitution as "an eduring but evolving statement of general values," . . . in fact the selection and accommodation of substantive values is left almost entirely to the political process and instead the document is overwhelmingly concerned, on the one hand, with procedural fairness in the resolution of individual disputes (process writ small), and on the other, with what might capaciously be designated process writ large-with ensuring broad participation in the processes and distributions of government. ${ }^{4}$

Yet it is not difficult to show that the constitutional theme of perfecting the processes of governmental decision is radically indeterminate and fundamentally incomplete. The process theme by itself determines almost nothing unless its presuppositions are specified, and its content supplemented, by a full theory of substantive rights and values-the very sort of theory the process-perfecters are at such pains to avoid. If that proposition, which this Article seeks to elaborate, is correct, it leaves us with a puzzle: why do thoughtful judges and scholars con-

with, or at least not against, Congress or state legislatures. Judicial review should continue to leave room for legislative action or so, at least, Justice Jackson suggested in defending equal protection analysis. See Railway Express Agency v. New York, 336 U.S. 106, 111-12 (1949) (Jackson, J., concurring) (preferring use of equal protection clause to use of due process clause to invalidate legislation, as former leaves government option of drafting more equitably framed legislation to regulate conduct). Some commentators have thought that a similar idea partly explained the appeal (for a time) of the First Amendment overbreadth doctrine. See, e.g., G. Gunther, Constitutional LaW 1134 (1975).

3. See, e.g., L. LuSkY, BY What RIGHT? (1975); Ball, Judicial Protection of Powerless Minorities, 59 IowA L. Rev. 1059 (1974); Black, The Unfinished Business of the Warren Court, 46 WAsh. L. Rev. 3, 8-9 (1970); Brest, The Supreme Court, 1975 Term-Foreword: In Defense of the Antidiscrimination Principle, 90 HARv. L. REv. 1, 6-12 (1976); Fiss, Groups and the Equal Protection Clause, in EQuality and Preferential Treatment 85, 130 (M. Cohen, T. Nagel \& T. Scanlon eds. 1977); Karst, The Supreme Court, 1976 Term-Foreword: Equal Citizenship Under the Fourteenth Amendment, 9l HARv. L. REV. 1, 8-10, 24-26 (1977); Tribe, Structural Due Process, 10 HARv. C.R.-C.L. L. REv. 269 (1975); Note, Mental Illness: A Suspect Classification?, 83 YaLE L.J. 1237 (1974). See generally Rostow, The Democratic Character of Judicial Review, 66 HARv. L. Rev. 193 (1952). Sometimes the concern for process is coupled with an effort to ground constitutional law in fundamental values, such as respect for individual dignity. See, e.g., Brest, supra, at 11 (prevention of stigmatic harms to particular individuals supports antidiscrimination principle in equal protection doctrine); Karst, supra, at 8 (participation in community decisionmaking processes contributes to self-respect).

4. J. Ely, Democracy and Disrrust 87 (1980) (footnotes omitted) [hereinafter cited as ELY]. 
tinue to put forth process-perfecting theories as though such theories could banish divisive controversies over substantive values from the realm of constitutional discourse by relegating those controversies to the unruly world of power?

\section{The Constitution's Openly Substantive Commitments}

One difficulty that immediately confronts process theories is the stubbornly substantive character of so many of the Constitution's most crucial commitments: commitments defining the values that we as a society, acting politically, must respect. Plainly, the First Amendment's guarantee of religious liberty and its prohibition of religious establishment are substantive in this sense. ${ }^{5}$ So, too, is the Thirteenth Amendment, in its abolition of slavery and repudiation of the Constitution's earlier, ostensibly procedural, protections of that institution. ${ }^{6}$

In many of its parts, the Constitution also evinces a substantive commitment to the institution of private property and to the contractual expectations that surround it. The just compensation clause of the Fifth Amendment is an obvious example. ${ }^{7}$ The contracts clause of article $\mathrm{I}$, section 10 is another. ${ }^{\mathrm{s}}$ The old substantive due process, which is obviously an important part of our constitutional history and thus significant for our understanding of what the Constitution is

5. See B. Bailyn, The Ideological Origins of the American Revolution 246-72 (1967).

6. See Note, The Thirteenth Amendment and Privale Affirmative Action, 89 YALE L.J. 399,406 (1979) (framers of amendment intended to guarantee blacks "meaningful freedom" by obliterating all vestiges of slavery). To say that the nation's experience with slavery shows the folly of incorporating substantive matters in the Constitution, see ELY, supra note 4, at 93, 100, $226 \mathrm{n} .68$, is simply to invert the lessons of our history.

7. Just compensation cases, arising under the Constitution or under statutes that Congress and the state legislatures have adopted in response to constitutional requirements, are a steady and continuing part of the business of the courts. See generally B. Ackerman, Private Property and the Constitution (1977).

8. Contracts clause cases, rarer than just compensation cases, are thought to be less important because the clause itself imposes no significant restriction. The conventional view is that the Supreme Court, in limiting the clause's protection to that against retroactive legislation, see Ogden v. Saunders, 25 U.S. (12 Wheat.) 213,303 (1827), rendered the clause less significant. The traditional learning holds that whatever residual importance the clause retained has disappeared. See Home Bldg. \& Loan Ass'n v. Blaisdell, 290 U.S. 398 (1934) (reasonable legislation, even if retroactive, disturbs no legitimate expectation interest of contracting parties). The Court, however, has on some 100 occasions since Ogden voided state statutes and municipal ordinances under the clause. Moreover, the Court that decided Blaisdell did not act as if that decision vitiated the clause. See, e.g., Wood v. Lovett, 313 U.S. 362 (1941) (state law that removed procedural rights from purchasers at a tax sale violates clause); Indiana $e x$ rel. Anderson v. Brand, 303 U.S. 95 (1938) (state teacher tenure law held to have created a binding obligation under clause). Indeed, the Court has very recently invalidated state legislation under the contracts clause. See, e.g., Allied Structural Steel Co. v. Spannaus, 438 U.S. 234 (1978); United States Trust Co. v. New Jersey, 431 U.S. 1 (1977). 
about, also served to protect the transactions and expectations to which the institution of private property gives rise. ${ }^{9}$ Whatever our views of the substantive due process heyday, most of us would readily concede that the framers of the 1787 Constitution adopted a federal system of government organization in order to, among other goals, help secure the institution of private property. ${ }^{10}$ When Madison, in his theory of faction, suggested that shifting the legislative responsibility for certain problems from the state to the national level could help assure that majorities would not trample minority rights, ${ }^{11}$ the problems he had

9. See, e.g., Coppage v. Kansas, 236 U.S. 1 (1915) (protecting employer's constitutional right under due process clause to choose not to hire union member employees); Lochner v. New York, 198 U.S. 45 (1905) (invalidating maximum hour work laws as violative of contractual liberties protected by Constitution).

A number of critics have charged that the old substantive due process is inconsistent with the language of the due process clause itself. See, e.g., Whitney v. California, 274 U.S. 357, 373 (I927) (Brandeis, J., concurring); ELY, supra note 4, at 18 ("[T]here is simply no avoiding the fact that the word that follows 'due" is 'process.' "). But the words that follow "due process" are "of law," and the word "law" seems to have been the textual point of departure for substantive due process. See, e.g., Hurtado v. California, 110 U.S. 516, 535-36 (1884):

It is not every act, legislative in form, that is law. Law is something more than mere will exerted as an act of power. It must not be a special rule for a particular person or a particular case, ... thus excluding, as not due process of law, acts of attainder, bills of pains and penalties, acts of confiscation, acts reversing judgments, and acts directly transferring one man's estate to another, legislative judgments and decrees, and other similar special, partial and arbitrary exertions of power under the forms of legislation.

The form that substantive due process analysis took has recently begun to receive scholarly attention. See Kennedy, The Structure of Blackstone's Commentaries, 28 Buffalo L. REv. 205 (1979); Miller, The Forest of Due Process of Law: The American Constitutional Tradition, in Due Process: Nomos XVIII 3 (J. Pennock \& J. Chapman eds. 1977). "Due process of $l a w$ " was elaborated through a theory of legislation founded upon ideals of separation of powers. The theory distinguished legislation from adjudication by assigning to adjudication the task of rearranging vested rights; it distinguished among types of legislation by asking whether the various types infringed vested rights; and it identified vested rights by treating the common law as a mirror of individual expectations, by regarding that which the common law protected-liberty of contract, for example-as something that individuals rightly presupposed, and upon which individuals justifiably relied. See T. Cooley, Constitutional Limitations 500-75 (7th ed. 1903).

The form of the old substantive due process doctrine is important here for two reasons. That the doctrine had form-and a form that drew upon such traditional sources of legal principles as ideas about the common law and separation of powers-suggests that the substantive due process cases were not some mad judicial tear, which we may today safely and gladly forget. See L. Tribe, American Constitutional LAw 434-36 (1978). Moreover, the fact that the form of the doctrine drew in part upon separation of powers concepts illustrates a more general point: the Constitution may appear in large part to address the structure and arrangement of government-process writ large and small-but the concerns that underlie and explain the structures and arrangements ordained by the Constitution are themselves undeniably substantive.

10. See Wood, Rhetoric and Reality in the American Revolution, 23 WM. \& MARX Q. 3 (3d Ser. 1966).

11. See, e.g., The Federalist No. 10 (J. Madison). 
in mind were largely economic; ${ }^{12}$ the minority rights the federal system would protect were, for the most part, rights of property and contract. ${ }^{13}$

Religious freedom, antislavery, private property: much of our constitutional history can be written by reference to just these social institutions and substantive values. That the Constitution has long addressed such matters, and often with beneficial effect, ought to surprise no one. What is puzzling is that anyone can say, in the face of this reality, that the Constitution is or should be predominantly concerned with process and not substance.

But our constitutional reality poses even deeper problems for process theorists. Even the Constitution's most procedural prescriptions cannot be adequately understood, much less applied, in the absence of a developed theory of fundamental rights that are secured to persons against the state-a theory whose derivation demands precisely the kinds of controversial substantive choices that the process proponents are so anxious to leave to the electorate and its representatives.

\section{The Substantive Roots of Procedural Norms}

Much of the Constitution does indeed appear to address matters of procedure. Sometimes the subject is adjudicative process-the process due to individuals who become defendants in criminal or civil litigation or targets of administrative actions. Elsewhere, the Constitu-

12. For example, witness which responsibilities the framers gave to the federal government-particularly the power to regulate interstate and foreign commerce. U.S. Consr., art. I, $\S 8$, cl. 3 . Many of the prohibitions of article $I, \S 10$, also have an economic cast: No State shall ... coin Money; emit Bills of Credit; make any Thing but gold and silver Coin a Tender in Payment of Debts; pass any . . . Law impairing the Obligation of Contracts ....

No State shall, without the Consent of the Congress, lay any Imposts or Duties on Imports or Exports . ...

No State shall, without the Consent of Congress, lay any Duty of Tonnage . . . .

13. See The Federalist No. 10, at 79 (C. Rossiter ed. 1961) ("But the most common and durable source of factions has been the various and unequal distribution of property. Those who hold, and those who are without property, have ever formed distinct interests in society. Those who are creditors, and those who are debtors, fall under a like discrimination."); G. Wood, The Creation of the American Republic 503-04 (1969) (federal bicameralism as means of protecting minority property rights).

It is a mistake to view the concern of the Federalists with property rights in contemporary terms. Property rights in the late 18th century partook more of status than of exchange; debtor legislation was perceived as threatening not only because it represented the loss of wealth but also because it portended the triumph of the "licentious," the distuption of an order of virtue and merit in society. See id. at 393-425. Yet, even if the concern with property is recast in 18 th-century terms, the protection of individual property rights remains intact as an aim of the Constitution. See id. at 609 ("The liberty that was now emphasized was personal or private, the protection of individual rights against all governmental encroachments, particularly by the legislature .... Government was no longer designed merely to promote the collective happiness of the people, but also ... 'to protect citizens in their personal liberty and their property' .....") 
tion focuses on representative process-including the process that governs the election of Congress, ${ }^{14}$ of the President, ${ }^{15}$ or of state representative bodies. ${ }^{16}$ That the subject in all these cases is procedure, however, is not to say that the meaning and purpose of the Constitution's prescriptions on each such subject are themselves merely procedural. There is no reason to suppose that "constitutive" rules-rules defining the basic structure of political and legal relations-can or should be essentially neutral on matters of substantive value.

The very dichotomy just drawn-between adjudicative and representative process-Twould prove incoherent without a substantive theory. How do we decide which form of participation the complaining individual may claim: the right to be heard as a litigant, or the right to be counted as a voter? The question whether individuals may insist on being heard by rulemakers, for whom they have already (directly or indirectly) voted, has bedeviled administrative law since the turn of the century. ${ }^{17}$ How the government chooses to deal with individuals-as individuals or en masse-cannot be dispositive. For, at least sometimes, government action that purports to deal with groups is unconstitutional precisely because it does not deal with individuals as such: the conclusive presumption decisions ${ }^{18}$ and the mandatory death penalty cases, ${ }^{19}$ however opaque they might otherwise be, establish this much, as does Justice Powell's opinion in Regents of the University of California v. Bakke. ${ }^{20}$ Conversely, in at least some circumstances, there is

14. See, e.g., U.S. Const., art. I, $\$ \S 2,3$.

15. See, e.g., id., art. II, $\S 1$.

16. See, e.g., Reynolds v. Sims, 377 U.S. 533, 568 (1964) (equal protection clause requires apportionment of state legislative seats by population).

17. See, e.g., Bi-Metallic Inv. Co. v. State Bd. of Equalization, 239 U.S. 441 (1915) (no hearing necessary before assessments of all taxable property uniformly increased); Londoner v. City of Denver, 210 U.S. 373 (1908) (hearing required before costs of local improvements are assessed to property owners on the basis of relative benefit).

18. See, e.g., Cleveland Bd. of Educ. v. LaFleur, 414 U.S. 632, 645 (1974) (mandatory maternity-leave rules creating an irrebuttable presumption violate due process clause in failing to recognize individual differences); Stanley v. Illinois, 405 U.S. 645, 656-57 (1972) (statute containing irrebuttable presumption that all unmarried fathers are incompetent to raise children is unconstitutionally overbroad). For a discussion of these and related cases, see L. TRIBE, supra note 9, at 1092-97.

19. See, e.g., Lockett v. Ohio, 438 U.S. 586, 605 (1978) (Eighth and Fourteenth Amendments require death penalty statutes to permit individualized consideration of mitigating factors for each defendant); Woodson v. North Carolina, 428 U.S. 280, 304 (1976) (opinion of Stewart, Powell, and Stevens, JJ.) (process must treat offenders on individualized basis in capital cases); Gregg v. Georgia, 428 U.S. 153, $197-98$ (1976) (death penalty held constitutional when statute is drafted to ensure jury consideration of individual circumstances of crime and offender).

20. 438 U.S. 265, 320 (1978) (Powell, J., announcing judgment of the Court) (relying on "personal rights" theory of equal protection clause to invalidate racial quotas in medical school admissions); see Tribe, Perspectives on Bakke: Equal Protection, Procedural Fairness, or Structural Justice?, 92 HARv. L. REv. 864, 867 (1979). 
no constitutional infirmity in relying only on representative, or even directly democratic, processes to deal with individuated grievances: individual zoning variances may be made the subject of local referendum;"2 and unions, as delegatees of federal power, 22 may bind members of bargaining units to the terms of wage bargains or, indeed, of individual grievance negotiations, even though the unions do not act as representatives of individuals as individuals. ${ }^{23}$

The question of whether adjudicative or representative process is required in a given context simply cannot be analyzed in terms of how fairly and accurately various participatory processes reflect the interests and inputs of those governed by them. Deciding what kind of participation the Constitution demands requires analysis not only of the efficacy of alternative processes but also of the character and importance of the interest at stake-its role in the life of the individual as an individual. That analysis, in turn, requires a theory of values and rights as plainly substantive as, and seemingly of a piece with, the theories of values and rights that underlie the Constitution's provisions addressing religion, slavery, and property.

Once one has decided whether the Constitution requires adjudicative or representative process in a particular setting, one must again rely on substantive values in elaborating the requirements of either procedural form. Consider first the problem of adjudicative process. Certainly the Fifth Amendment's self-incrimination and double jeopardy clauses embody concerns for protecting individual dignity in the criminal process. $^{24}$ A substantive concern for individual "privacy" necessarily underpins the Fourth Amendment. ${ }^{25}$ Other superficially procedural

21. See, e.g., City of Eastlake v. Forest City Enterprises, Inc., 426 U.S. 668, 676-77 (1976). But see L. TribE, supra note 9, at 493-95.

22. See Stcele v. Louisville \& N.R.R., 323 U.S. 192, 202 (1944).

23. See, e.g., Hines v. Anchor Motor Freight, Inc., 424 U.S. 554, 563-64 (1976); Vaca v. Sipes, 386 U.S. 171, 182 (1967).

24. See, e.g., Miranda v. Arizona, 384 U.S. 436, 457.58 (1966) ("incommunicado interrogation" is "destructive of human dignity" and conflicts with privilege against selfincrimination); Green v. United States, 355 U.S. 184, 187 (1957) ("underlying idea" behind guarantee against double jeopardy "is that the State... should not be allowed to make repeated attempts to convict an individual for an alleged offense, thereby subjecting him to embarrassment, expense and ordeal and compelling him to live in a continuing state of anxiety and insecurity").

25. Payton v. New York, 48 U.S.L.W. 4375, 4380,4383 (U.S. April 15, 1980) (No. 78-5420) (absent exigent circumstances, Fourth Amendment requires warrant to arrest person in home even with probable cause); Griswold v. Connecticut, 381 U.S. 479, 485 (1965) (Fourth Amendment implies "right to privacy"); Boyd v. United States, 116 U.S. 616, 630 (1886) (Fourth Amendment applies to all government invasions of "the sanctity of a man's home and the privacies of life"). That privacy alone cannot account for the Fourth Amendment, see ELY, supra note 4, at 96, 172, obviously does not show that procedural concerns alone-such as limiting official discretion--can suffice to explain it. But see id. at 97. 
provisions of the Constitution, such as the rights to counsel, confrontation, bail, and jury trial, echo similar themes; they function, often at some cost to the efficiency and accuracy of fact-finding, ${ }^{26}$ to prevent the government from treating individuals in the criminal process as though they were objects. ${ }^{27}$

Even outside the criminal context, elaborating rights of adjudicative process requires recourse to a substantive theory. Procedural due process rights are not simply means of protecting whatever "entitlements" happen to be conferred by legislation or administrative regulation. Otherwise, the drafters of an entitlement could frame it in the procedural terms of their choice, and the constitutional guarantee would be reduced to a right to receive whatever process the drafters had defined as due. ${ }^{28}$ But that view has been repeatedly rejected by the Supreme Court, which has never fully embraced a purely positivist theory of procedural due process. ${ }^{20}$ The only alternative theories, however, are ones that posit a right to individual dignity, or some similarly substantive norm, as the base on which conceptions of procedural fairness are constructed. ${ }^{30}$

If process is constitutionally valued, therefore, it must be valued not only as a means to some independent end, but for its intrinsic characteristics: being heard is part of what it means to be a person. ${ }^{31}$ Pro-

26. See generally Packer, Two Models of the Criminal Process, 113 U. PA. L. REv. 1, 6-23 (1964) (tension in criminal process between crime control model, seeking efficient, expeditious and reliable screening and disposition of persons suspected of crimes, and due process model, seeking maintenance of dignity and autonomy of individual).

27. See generally C. Fried, An ANatomy of Valurs $125-32$ (1970) (criminal procedure has "expressive aspects" and implicitly evidences societal ends).

28. One difficulty with a positivist theory of entitlements is that, if the Constitution requires government to deliver only what it promises, government is likely to respond by promising little. The present confusion in the law of procedural due process is strikingly illustrated by the Supreme Court's failure to require even the government to honor its procedural commitments. See, e.g., United States v. Caceres, 440 U.S. 741 (1979) (evidence obtained by method contrary to agency regulations not excluded under exclusionary rule).

29. See, e.g., Vitek v. Jones, 100 S. C. 1254, 1261-62 (1980); Carey v. Piphus, 435 U.S. 247, 266 (1978); Arnett v. Kennedy, 416 U.S. 134 (1974).

30. See, e.g., Michelman, Formal and Associational Aims in Procedural Due Process, in Due Process: Nomos XVIII 126, 127 (J. Pennock \& J. Chapman eds. 1977) (due process vindicates substantive values of "participation" and "revelation"); Saphire, Specifying Due Process Values: Toward a More Responsive Approach to Procedural Protection, $127 \mathrm{U}$. PA. L. REv. 111, 117-25 (1978) (due process standard should measure whether conduct in question comports with basic notions of fairness and dignity). Values like accuracy do not by themselves justify a constitutional right to procedural due process. "Accuracy" is inevitably an instrumental concept. To give it content, to decide which procedures a concern for accuracy requires, we must look to the entitlement in question. The legislature, in drafting the statute conferring the entitlement, may deliberately define it in ambiguous terms. If the entitlement is not precisely defined, a concern for accuracy presumably would not result in elaborate procedure. Thus an instrumentalist approach leaves an opening for positivism.

31. What process is due depends upon what is at stake in a given case. The interest at 
cess itself, therefore, becomes substantive. There is a curious irony here. One who holds that constitutional law should aim chiefly to perfect process is apparently unable to treat process as itself valuable. For, to see why process would itself be valuable-intrinsically so-is to see why the Constitution is inevitably substantive. Instead, the processperfecter must treat process as ultimately instrumental, as but a means to other ends, and thus must regard as secondary what he would at the same time celebrate as primary. ${ }^{32}$

The process theorist is similarly confounded by questions about the right to vote-the quintessential procedural right in the realm of politics. Voting-rights issues commonly take one of two forms. One set of issues concerns who votes. Is the electorate to include racial minorities, women, District of Columbia residents, eighteen-year-olds? ${ }^{33}$ Is it to include only property owners, only property owners and parents, only residents, only citizens ${ }^{34}$ What of the disenfranchisement of children ${ }^{35}$ Who votes, it turns out, is a profoundly substantive question. ${ }^{36}$ For who participates-who counts-in the electoral process is a question that must precede any inquiry into the fairness of the process itself. The issue goes not to fairness procedurally, but to our sense of who constitutes a political community, and of which relations in society must be horizontal rather than vertical, fraternal rather than hierarchical. And if any question is plainly substantive, that question is fundamentally so. ${ }^{37}$

The second set of issues concerns how voting power is to be allocated among those who are included within an electoral constituency. Sometimes, in this context, the Supreme Court looks to whether the election

stake is pertinent to what procedures, in a given circumstance, are consistent with individual dignity. See, e.g., Cafeteria \& Restaurant Workers Local 473 v. McElroy, 367 U.S. 886,895 (1961) (consideration of what procedures due process may require under any given set of circumstances must begin with determination of private interest affected); Note, Specifying the Procedures Required by Due Process: Toward Limits on the Use of Interest Balancing, 88 HaRv. L. REv. 1510, 1528-30 (1975) (process due depends on interest at stake).

32. See ELY, supra note 4, at 95-96.

33. See U.S. Const. amends. XV, XIX, XXIII, XXVi.

34. See City of Phoenix v. Kolodziejski, 399 U.S. 204 (1970) (franchise cannot be limited to property owners); Kramer v. Union Free School Dist. No. 15, 395 U.S. 621 (1969) (franchise in school board election cannot be limited to property owners and parents); Holt Civic Club v. City of Tuscaloosa, 439 U.S. 60 (1978) (nonresidents can be denied vote even in jurisdiction that taxes and regulates them); Rosberg, Aliens and Equal Protection: Why Not the Right to Vote?, 75 MICH. L. Rev. 1092 (1977).

35. See Developments in the Law-The Constitution and the Family, 93 HARv. L. REv. 1156, 1201-02, 1221-42, 1350-83 (1980) [hereinafter cited as Developments].

36. Conventionally, it is treated as if it were a matter of procedure. See, e.g., ELY, supra note 4 , at 98.99 .

37. Consider the question whether fetuses are persons with rights, a question raised by the right-to-life critique of Roe v. Wade, 410 U.S. 113 (1973). See L. TRIBE, supra note 9, at 926-29. 
is one that chooses representatives or one that resolves a one-shot issue, ${ }^{38}$ or whether voters are voting as individuals or as, say, property owners..$^{39}$ But generally, the Court has enforced the famous rule announced in the reapportionment cases: one person, one vote. ${ }^{40}$ The obvious substantive underpinnings of this rule-its role as an expression of the equal respect in which we as a society aspire to hold each individual ${ }^{41}$-all of this the theorists of perfecting process must ignore. They can defend the rule only hesitantly, claiming, for example, that it is merely a matter of administrative convenience. ${ }^{42}$ Again we observe the irony already revealed in the adjudicative process cases: because embracing process for its own sake means embracing process as substance-as an expression of the value in which we would hold individuals-theorists who would defend constitutional law as ultimately reducible to the quest for perfection of process cannot themselves treat process as primary. ${ }^{43}$ Again the puzzle deepens: as the next section will show, theorists of perfecting process are not only undercut by their inability affirmatively to advocate process as such, but their negative critique of obstructed process is stunted as well.

\section{The Quandary of Whom to Protect}

For those who would fill the gaps left by the Constitution's ambiguities and silences with representation-reinforcing principles, perhaps the core "process value" is the value of protecting certain minorities from perennial defeat in the political arena. The theme was anticipated by John Marshall; ${ }^{44}$ it assumed a central role for Harlan Fiske Stone, ${ }^{4 \bar{J}}$

38. See Town of Lockport v. Citizens for Community Action at the Local Level, Inc., 430 U.S. 259 (1977) (sustaining constitutionality of electoral procedures requiring concurrent majorities for restructuring constituent political units).

39. See Salyer Land Co. v. Tulare Lake Basin Water Storage Dist., 410 U.S. 719 (1973) (sustaining rule tantamount to "one acre, one vote" in composition of special water districts).

40. See, e.g., Reynolds v. Sims, 377 U.S. 533, 567-68 (1964).

41. See R. Dworkin, Taking Rigits Seriously 273 (1977).

42. See, e.g., ELY, supra note 4, at 124.

43. Nor can such theorists rest with a view that accepts a purely instrumental role for procedural norms and defends the constitutional plan as an indirect scheme for implementing substantive values that are not authoritatively established by the Constitution itself. For if the realization of such substantive values is the Constitution's aim, then their elaboration is appropriately the task of all who would interpret the Constitution.

44. See McCulloch v. Maxyland, 17 U.S. (4 Wheat.) 316, $435-36$ (1819) (state has no power to $\operatorname{tax}$ federal instrumentality because it would thereby act on national population, not represented in its legislature).

45. United States v. Carolene Prods. Co., 304 U.S. 144, 152 n.4 (1938) (strict judicial review for statutes that are directed against "discrete and insular minorities"); South Carolina State Highway Dep't v. Barnwell Bros., 303 U.S. 177, 184 n.2 (1938) (commerce clause may prohibit legislation burdening political outsiders). 
it signally motivated Earl Warren; ${ }^{40}$ and it has been elaborated by numerous scholars, ${ }^{47}$ most powerfully in the work of John Ely. ${ }^{48}$ The idea seems as simple as it sounds reasonable: governmental action that burdens groups effectively excluded from the political process is constitutionally suspect. In its most sophisticated form, the resulting judicial scrutiny is seen as a way of invalidating governmental classifications and distributions that turn out to have been motivated either by prejudiced hostility or by self-serving stereotypes. ${ }^{49}$

It all sounds pretty good-until we ask how we are supposed to distinguish such "prejudice" from principled, if "wrong;" disapproval. Which groups are to count as "discrete and insular minorities"? Which are instead to be deemed appropriate losers in the ongoing struggle for political acceptance and ascendancy?

To begin with, of course, the theory must clearly distinguish itself from its reductio ad absurdum: "whichever group happens to lose the political struggle or fails to command the attention of the legislature . . . is-by that fact alone-a discrete and insular minority." "3o How about focusing on immutability, discreteness, insularity? For the process theorist, all such features might seem helpful in suggesting why a legislature would regard some groups as "different" and thus fall prey to cruel or self-servingly careless stereotyping. Or such features may signal why other groups would fail to interact with a group considered "different," or to engage in the usual protective logrolling.

But features like immutability are neither sufficient ${ }^{51}$ nor necessary. ${ }^{52}$

46. See Ely, The Chief, 88 HARv. L. REv. 11, 12 (1974) (Warren sought to ensure that machinery of democratic process does not become self-serving organ of privileged class).

47. See, e.g., L. LuSKY, supra note 3, at 11-12; L. TRIBE, supra note 9, passim.

48. See ELY, supra note 4, at 135-79.

49. See $i d$. at 153-70.

50. Fiss, The Supreme Court, 197S Term-Foreword: The Forms of Justice, 93 Harv. L. Rrv. 1, 8 (1979); see Sugarman v. Dougall, 413 U.S. 634, 657 (1973) (Rehnquist, J., dissenting) (no "extraordinary ingenuity" needed for lawyers to "find insular and discrete" minorities at every turn in the road").

51. Immutability by itself is plainly not sufficient. Intelligence, height, and strength are all immutable for a particular individual, but legislation that distinguishes on the basis of these criteria is not generally thought to be constitutionally suspect. Discreteness and insularity are also insufficient: chiropractors may be a discrete and insular minority, but legislation that singles them out would not be subject to strict scrutiny on that basis alone. Even all three factors in combination may not be sufficient. Old age is an immutable characteristic, and the elderly may well be a discrete and insular minority. However, age is not per se a suspect criterion of classification. See Massachusetts Bd. of Rctirement v. Murgia, 427 U.S. 307 (1976) (per curiam). For background discussion, see L. TRIBE, supra note 9 , at 1077-82.

52. Alienage is properly treated as a classification at least partially suspect, despite its mutable character. See, e.g., Nyquist v. Mauclet, 432 U.S. I (1977) (denying state scholar- 
For in looking at social attitudes toward groups, one cannot simply play Linnaeus and engage in taxonomy. One cannot speak of "groups" as though society were objectively subdivided along lines that are just there to be discerned.53 Instead, people draw lines, attribute differences, as a way of ordering social existence-of deciding who may occupy what place, play what role, engage in what activity. Thus, in order to justify the role of chattel that blacks initially played in our society, we may have differentiated that role by describing it in terms of the most obvious distinguishing feature of the people who played it, thus equating race and role. ${ }^{54}$ This equation, and thus the "group," survived the Civil War and the Thirteenth Amendment. It did so not simply by reason of confusion or inertia, but because the role that society allowed blacks remained partly unchanged; thus the need to justify the role by differentiating it, by seeing not the role but the group- "inferior" blacks capable of nothing better anyway-persisted. ${ }^{55}$

The temptation to think of groups as simply given is exacerbated by the complex interaction between social attitudes and those identified as group members. Individuals who find themselves so identified may indeed see themselves as group members; because they approve of the options that society leaves them and want to protect those options, they identify the options with themselves, the differentiated "group." "Alternatively, assertion of group status may be a form of internal exile, a way of repudiating the limited possibilities for action that the larger social structure would allow, a choice of "exit" rather than "voice."

ship aid to resident aliens who choose to remain noncitizens violates equal protection). And even if race or gender became readily mutable by biomedical means, I would suppose that laws burdening those who choose to remain black or female would properly remain constitutionally suspect.

53. This point is neatly illustrated by a passage quoted by Foucault, in which Borges cites a Chinese encyclopedia's assertion that "animals are divided into: (a) belonging to the Emperor, (b) embalmed, (c) tame, (d) sucking pigs, (e) sirens, (f) fabulous, (g) stray dogs, (h) included in the present classification, (i) frenzied, (j) innumerable, (k) drawn with a very fine camelhair brush, (l) et cetera, (m) just having broken the water pitcher, (n) that from a long way off look like flies." M. Foucault, The Order of Things $x v$ (1970).

54. See W. Jordan, White Over Black (1968).

55. See C. V. Woodward, The Strange Career of Jim Crow (2d ed. 1966).

56. Individuals who disapprove of the options that society presents them may nevertheless accept their treatment as a differentiated group, and accept as natural or inevitable their inferior status. Even individuals with options more favorable than those of most group members may accept the social characterization of the group in order to differentiate themselves from the group. See Castaneda v. Partida, 430 U.S. 482, 503 (1977) (Marshall, J., concurring); $c f$. G. WeInberg, Society and the Healthy Homosexual. 74.82 (1972) (homosexual self-loathing, contempt, and prejudice parallel societal attitudes).

57. Thus, some blacks may differentiate themselves as a way of rejecting, or of expressing a critical judgment about, the options with which society at large leaves them. 
This way of thinking about groups, I believe, captures not only much of the dynamics of race, but also much of the social significance of religion, alienage, gender, sexual preference, legitimacy, wealthtraits we as a society commonly use in separating out groups. ${ }^{58}$ Views about the "differentness" of groups generally, therefore, may reflect an interacting set of judgments about activities or options or roles, expressed sometimes harmoniously and sometimes dialectically by both "we" and "they." reveals prejudicial stereotypes must, at bottom, spring from a disagreement with the judgments that lie behind the stereotype: judgments about the propriety of the options left to individuals or the burdens imposed on them.

Consider several illustrations. Burglars are subject to widespread hostility: indeed, the activity that defines the group is everywhere legislatively prohibited. Are burglars therefore a "suspect class"? Of course not. Suspect status is unthinkable-but only because of the substantive value we attach to personal security, and the importance for us of the system of private property and its rules of transfer, which the burglary prohibition preserves. ${ }^{60}$ If we speak of burglars as a class, we do so as a way of giving form to our view that burglary is a "different" activity, different not so much because burglars visibly define a group as because we disapprove of the activity, deny it any claim to protection as a right.

Homosexuals, too, are subject to widespread hostility; legislation penalizing homosexuals and homosexual practices is common. ${ }^{\text {11 }}$ Homosexuals often do not identify themselves by sexual preference when acting politically, and generally do not "come out of the closet" to refute the traditional stereotypes. ${ }^{62}$ But even if they did, legislation might be unaltered. Coming out of the closet could dispel ignorance, but it may not alter belief. Legislators may see homosexuals as "dif-

Cf. A. Hirschman, Exit, Vorce, ANd Loyalty 108-12 (1970) (American black power movement advocates collective program for blacks as group and rejects traditional pattern of upward social mobility for individual, selected blacks).

58. See Fiss, supra note 3, at 124-33; cf. G. Myrdal, AN American Dilemma 27-30 (1944).

59. See Ely, The Constitutionality of Reverse Racial Discrimination, 41 U. CHI. L. REv. 723, 732 (1974).

60. See ELY, supra note 4, at 154 .

61. See Rivera, Our Straight-Laced Judges: The Legal Position of Homosexual Persons in the United States, 30 Hastings L.J. 799 (1979).

62. See ELY, supra note 4, at 163 ("serious social costs" of encountering prejudice upon admission); C. Reich, The SoRCERER of Bolinas ReEF 71-73 (1976) (fear of societal opprobrium caused repression of homosexuality). But see L. HuMPhreYs, OUT of the Closets (1972) (chronicling recent organizational activism, political action, and violence by homosexuals in response to oppression). 
ferent" not out of ignorance, but on principle-on the basis of a morality that treats certain sexual practices as repugnant to a particular view of humanity, and thus regards people who engage in those practices as "other." "63 Such legislation can be rejected only on the basis of a principle that is equally substantive: a view of what it means to be a person, and to have a sexual identity. ${ }^{64}$ Process and prejudice thus seem profoundly beside the point. Any constitutional distinction between laws burdening homosexuals and laws burdening exhibitionists, between laws burdening Catholics and laws burdening pickpockets, must depend on a substantive theory of which groups are exercising fundamental rights and which are not. ${ }^{65}$

Indeed, even laws putting blacks and women "in their place"banning racial intermarriage, say, or excluding women from combatare likely to reflect neither simple hostility nor self-serving blindness but $a$ substantive vision of proper conduct-a vision that no amount of attention to flaws in the political process could condemn or correct. Accordingly, the idea of blacks or women as properly segregated beings can be rejected only by findirg a constitutional basis for concluding that, in our society, such hierarchical visions are substantively out of bounds, at least as a justification for government action. ${ }^{66}$ And such a finding would in turn entail a theory of unenumerated substantive rights, rights at best suggested by constitutional text and history, rights whose necessarily controversial elaboration the process theorists seek to eschew. ${ }^{67}$

63. See, e.g., Doe v. Commonwealth's Attorney for City of Richmond, 403 F. Supp. 1199, 1202 (E.D. Va. I975), aff'd mem., 425 U.S. 90I (1976) ("ancestry" of state statute prohibiting sodomy goes back to Judaic and Christian law); Barrett, Legal Homophobia and the Christian Church, 30 Hastincs L.J. 1019 (1979) (arguing that Christian morality is responsible for legal homophobia).

64. See Karst, The Freedom of Intimate Association, 89 YALE L.J. 624, 633-35 (1980).

65. See Developments, supra note 35 , at 1176 n.119.

66. See, e.g., Graig v. Boren, 429 U.S. 190, 210 n.23 (1976) (dictum) (disapproving earlier decision that upheld occupational exclusions of women); Loving v. Virginia, 388 U.S. 1 (1967) (invalidating ban on racial intermarriage). If, as some suggest, see, e.g., ELy, supra note 4 , at $256 \mathrm{n} .92$, a governmental decision to impose a burden could be defended simply by showing that the decision reflects "a bona fide feeling that [the burdened choice] is immoral," $i d$., then even racial segregation would be sustainable.

67. Even assuming that laws burdening groups such as women are founded on no moral convictions, a process-based analysis is still fatally inadequate. Although legislation discriminating against women does not, at least superficially, reflect hostility toward women, and despite the fact that women are not a minority, there is nonetheless reason, a process theorist might argue, for strict judicial scrutiny of such legislation. Male legislators no doubt frequently regard women as "they" rather than "we." See ELY, supra note 4, at 164 . In process terms, however, this is a weak case. Arguably, all that keeps women from full participation is the fact that many women (as well as men) accept a view of society in which women are subject to men or are otherwise inappropriate participants in public life. But that view of society is increasingly controversial. To 
The crux of any determination that a law unjustly discriminates against a group-blacks, or women, or even men ${ }^{68}$-is not that the law emerges from a flawed process, or that the burden it imposes affects an independently fundamental right, ${ }^{69}$ but that the law is part of a pattern that denies those subject to it a meaningful opportunity to realize their humanity. Necessarily, such an approach must look beyond process to identify and proclaim fundamental substantive rights. Whatever difficulties this may entail, it seems plain that important aspects of constitutional law, including the determination of which groups deserve special protection, can be given significant content in no other way. Thus it is puzzling indeed that process-based approaches-designed to deny the need for, and legitimacy of, any such substantive theoryshould nonetheless continue to find such articulate proponents and persist in attracting such perceptive adherents.

\section{The Closed Circle of Political Openness}

If protecting minorities requires a theory of substantive rights, might another value, that of "political openness"-of clearing the channels for change through speech and voting-be salvaged as a unifying theme for the process-minded?70 First Amendment theorists such as Alexander Meiklejohn have pursued this general line, with varying degrees of success. ${ }^{71}$ But there are at least three fundamental difficulties with any effort to reduce substantive rights to mere mechanisms for channelclearing. The first problem is the inherently incomplete nature of channel-clearing as an aim. Why should politics be open to equal

conclude today that women are an "excluded" group is simply to challenge the support of many women and men for contemporary legislation. Thus only sexist laws enacted long enough ago may be struck down as mere expressions of prejudicial stereotypes. See $i d$. at 166-67.

Disputes over the place of women, however, are hardly a recent development. See E. Pagels, The Gnostic Gospels 59-63 (1979) (tracing Gnostic treatment of women as equals); A. Kelly, Eleanor of Aquitaine ANd the Four Kings 163-64 (1950) (women of late 12thcentury Poitevin court sat in judgment upon points of courtly love). The fact of contemporary dispute is thus not necessarily a sign of progress. But if the idea of equal rights for women is a perpetually contested concept, then the constitutionality of legislation that treats men and women differently cannot turn, as process theorists might argue, on whether such legislation preceded or followed dispute about the status of women.

68. See, e.g., Orr v. Orr, 440 U.S. 268 (1979) (state statutory scheme cannot exempt women from alimony obligations imposed on men).

69. Neither drinking age, see Craig v. Boren, 429 U.S. 190 (1976), nor age of expiration of parental support obligations, see Stanton v. Stanton, 421 U.S. 7 (1975), involve independently fundamental rights-but in both areas the Supreme Court has invalidated gender-based lines that lock the sexes into their traditional roles.

70. See ELY, supra note 4, at 105-34.

71. See A. Meiklejohn, Free Speech and Its Relation to Self-Government 27 (1948). 
participation by all? Doesn't that norm itself presuppose some substantive vision of human rights? Why wouldn't a vision rich enough to support a reasonably complete theory of political openness also suffice to generate a theory of which substantive claims individuals may make against the majority?

The second problem is the absence of any plausible stopping point for channel-clearing theories. If the system must be open to change through peaceful persuasion, how do we distinguish between example and advocacy or between demonstration and assertion as forms of persuasion? If we do not draw some such distinction, life-style choices that seek to convince by demonstration-communal living arrangements or homosexual marriage, for example-are entitled to constitutionally protected status. Surely that is not what process theorists have in mind! Efforts to draw the necessary distinctions, however, are inevitably unsatisfactory. To accord special protection to advocacy alone is to censor those messages that can be conveyed only by example. Moreover, dichotomies such as speech and conduct, expression and action, or persuasion and instruction, do not in truth separate. ${ }^{72}$

If the acts of individuals may be demonstrations, and hence forms of persuasion, may not the same be said of the acts of government? ${ }^{73}$ The actions of government define expectations, confer legitimacy, establish a status quo, and thus necessarily shape the nature and distribution of interests and attitudes in society itself. The state shapes society almost as much as society shapes the state: this is the third problem that any channel-clearing theory must confront-but cannot surmount without losing its "procedural" status.

Government subsidies to "major" political parties, for example, or the failure of state governments to provide funds to compensate school districts lacking "rich" property tax bases, are government actions that affirm some aspects of the status quo as desirable, and others as inevitable. Such government actions are at present constitutional, ${ }^{74}$ as are governmental decisions that inculcate the young with the standard public virtues and defeat the self-defining, value-forming, and poweramassing efforts of all but the more standard social groupings. ${ }^{\top 5}$ Unable

72. See, e.g., L. TRIBE, supra note 9, at 598-601; ELY, supra note 4, at 113 n.".

73. See Yudof, When Governments Speak: Toward A Theory of Government Expression and the First Amendment, 57 Tex. L. Rev. 863 (1979).

74. See Buckley v. Valeo, 424 U.S. I (1976); San Antonio Independent School Dist. v. Rodriguez, 411 U.S. 1 (1973). But see Serrano v. Pricst, 5 Cal. 3d 584, 487 P.2d 1241, 96 Cal. Rptr. 601 (1971) (interpreting state constitution as creating a cause of action for violation of equal protection in suit to invalidate property tax funding of public schools).

75. Compare, e.g., Moore v. City of East Cleveland, 431 U.S. 494 (1977) (protecting extended families) with Village of Belle Terre v. Boraas, 416 U.S. 1 (1974) (households of 
to support a challenge to such exercises of power, a truly procedural channel-clearing theory seems doomed to irrelevance, for without such challenge government may well be able to shape the "will" of the governed in the image of those who govern, ${ }^{76}$ reducing consent and representation to all but empty ideals.

This should not seem too surprising: that domination can appear in the guise of democracy is hardly a novel observation in the late twentieth century. The puzzle is that the failure of process-based theories even to speak to this danger should be so readily and persistently excused or overlooked.

\section{A Broader Role for Constitutional Theory}

One final and closely related puzzle-a puzzle that may follow from the very aspiration of process-based theories to purge constitutional discourse of inevitably controversial claims about substantive rights and values-is the willingness of so many to embrace process-based theories in the face of their virtually total incapacity to inform the content of public discussion, debate, and decision. One can perhaps understand the appeal to judges of a theory purporting to instruct them that they are to construe the Constitution so as to reinforce representation, that is, fill in the blanks so as to perfect democracy. But what can be the appeal of such a theory to an elected representative-especially one who regards the Constitution as addressed to all who govern, ${ }^{77}$ and who accordingly wonders whether some of the "interests" of his constituents ought, as a constitutional matter, to be resisted rather than represented? ${ }^{78}$ And what can be the appeal of such a theory to a citizen who regards the Constitution as addressed to the people at large, and who, accordingly, asks which of his preferences-for exploiting the poor, perhaps, or for denigrating ethnic minorities-the citizen ought to suppress or even change?

unrelated individuals not protected); compare NAACP v. Button, 371 U.S. 415 (1963) (group legal services protected) with Garcia v. Texas State Bd. of Medical Examiners, 384 F. Supp. 434 (W.D. Tex. 1974), aff'd mem., 421 U.S. 995 (1975) (group health plans not).

76. Ely notes this phenomenon in connection with his discussion of the idea of progress as an organizing basis for constitutional law: "[T]oday's judicial decision (no matter what its source of judgment) will inevitably have an important influence on the values of tomorrow's majority." ELY, supra note 4, at 70. Cf. id. at 165 (societal stereotypes accepted by the stereotyped). He does not, however, generalize this insight to government action generally.

77. See Linde, "Clear and Present Danger" Reexamined: Dissonance in the Brandenburg Concerto, 22 STAN. L. REv. 1163 (1970); Linde, Due Process of Lawmaking, 55 NEB. L. REv. 197 (1976).

78. See H. Pitkin, The Concept of Representation (1967). 
Perhaps the impoverished relevance of the Constitution for everyone except judges under a process-based theory is to be offset in some way by the theory's supposed ability to improve constitutional argument, analysis, and adjudication in the judicial branch. But are we really to believe that the way judges decide cases will be powerfully and beneficially affected by theories linking the judiciary's constitutional role to the supposed failures of political process? Might not the care and humility that we are entitled to expect of judges be undermined if judges were indeed persuaded that much judicial activism is simply a corollary of democracy?

Most process-based theorists and their followers evidently have seen little point in analyzing what the general acceptance of their views would be likely to do to the actual course of constitutional argument and decision. ${ }^{79}$ The views they espouse apparently strike chords so responsive, accord with beliefs so deep, that inquiry into probable effects-like close attention to counter-examples and logical gapsseems beside the point. But if this is so, then we are left with a final puzzle, one to be explored in a later essay: what does it say about our situation, and about the prospect for constitutional theory, that views so deeply problematic continue to exert so powerful a grip upon our thought?

79. But see ELY, supra note 4, at 102 n.* (concern over effect of theory on protection of civil liberties). 